\title{
Caesarean section rates in South Africa: A case study of the health systems challenges for the proposed National Health Insurance
}

\author{
G C Solanki, ${ }^{1,2,3}$ BChD, BA Hons, MSc, DrPH; J E Cornell, ${ }^{4}$ BA, Perf Dip, MA, DHMEF, PhD; \\ E Daviaud, ${ }^{1}$ MSc (Economics, Health Economics), MPhil (Sociology of Development); S Fawcus, ${ }^{5}$ MA, MB BCh, FRCOG \\ ${ }^{1}$ Senior Specialist Scientist, Health Systems Research Unit, South African Medical Research Council, Cape Town, South Africa \\ ${ }^{2}$ Honorary Research Associate, Health Economics Unit, School of Public Health and Family Medicine, Faculty of Health Sciences, University of \\ Cape Town, South Africa \\ ${ }^{3}$ Principal Consultant, NMG Consultants and Actuaries, Cape Town, South Africa \\ ${ }^{4}$ Director of Institutional Development and Planning (retired), Nelson Mandela School of Public Governance, University of Cape Town, South Africa \\ ${ }^{5}$ Senior Scholar and Professor Emeritus, Department of Obstetrics and Gynaecology, Faculty of Health Sciences, University of Cape Town, South \\ Africa
}

Corresponding author: G C Solanki (geetesh.solanki@mrc.ac.za)

Broader policy research and debate on the issues related to the planning of National Health Insurance (NHI) in South Africa (SA) need to be complemented by case studies to examine and understand the issues that will have to be dealt with at micro and macro levels. The objective of this article is to use caesarean section (CS) as a case study to examine the health systems challenges that NHI would need to address in order to ensure sustainability. The specific objectives are to: (i) provide an overview of the key clinical considerations related to CS; (ii) assess the CS rates in the SA public and private sectors; and (iii) use a health systems framework to examine the drivers of the differences between the public and private sectors and to identify the challenges that the proposed NHI would need to address on the road to implementation.

S Afr Med J 2020;110(8):747-750. https://doi.org/10.7196/SAMJ.2020.v110i8.14699

As proposed in the National Health Insurance Bill, ${ }^{[1]}$ National Health Insurance (NHI) will be a strategic purchaser of healthcare services for the entire South African (SA) population. There is a need for broader policy research and debate on the planning and implementation of NHI to be complemented by case studies to examine and understand the issues that will need to be dealt at a more micro level.

\section{Objectives}

To use caesarean section (CS) as a case study to examine the health systems challenges that $\mathrm{NHI}$ would need to address in order to ensure sustainability. This case study has been chosen because: (i) maternal and child health is a major public health concern in SA, with 1.2 million recorded births in 2018; ${ }^{[2]}$ (ii) there is growing local and global concern about the appropriateness and safety of increasing CS rates; ${ }^{[3]}$ and (iii) there is a substantial difference between reported CS rates in the SA private and public sectors. ${ }^{[4]}$ This difference provides an ideal opportunity to assess and understand the underlying health systems drivers and how these would need to be addressed in an NHI environment. The specific objectives of the paper are to: (i) provide an overview of the key clinical considerations related to CS; (ii) assess the CS rate in the SA public and private sectors; and (iii) examine the drivers of differences between the public and private sectors and use a health systems framework to identify the challenges that the proposed NHI would need to address on the road to implementation.

\section{CS: The clinical considerations}

When indicated for health reasons, CS is an important surgical intervention to save lives of women and children. However, unnecessary CS (without medical/obstetric indication) should be avoided, as maternal mortality is three times higher for CS than for normal vaginal delivery (NVD) ${ }^{[5]}$ which is associated with fewer complications and is more sustainable for healthcare systems. ${ }^{[6]}$ Most healthy women prefer to give birth via NVD. ${ }^{[7,8]} \mathrm{A}$ woman who has had a CS is more likely to require one for subsequent births, thus increasing the CS rate.

The 2015 World Health Organization (WHO) statement, ${ }^{[8]}$ based on country data, demonstrates that CS rates $>10-15 \%$ conferred no further benefit in reducing maternal and perinatal mortality. In many countries, CS rates are consistently higher than is considered medically justifiable, ${ }^{[3]}$ and are rising, leading to debates about appropriate rates and concern about the costs associated with inappropriately high rates. ${ }^{[9,10]}$ For many low-income countries, CS rates are too low to save lives. The WHO statement therefore recommends that 'Every effort should be made to provide CS to women in need, rather than striving to achieve a specific rate', and further recommends against CS on maternal request based on the finding of increased maternal mortality for CS compared with vaginal delivery. ${ }^{[5]}$ Further reviews of the relationship between CS rates and the reduction of maternal and newborn mortality suggest that CS rates $>20 \%$ do not confer benefit in reducing mortality. However, if reduction of maternal and newborn morbidity (e.g. severe perineal tears, newborn hypoxic brain injury) is taken into account, rates $>20 \%$ may be acceptable. ${ }^{[11]}$

There is global (and in-country) inequity in provision of safe CS, with the case fatality rate (CFR) varying from 21.9 per 100000 CSs in The Netherlands ${ }^{[12]}$ to an average of 760 for low- to middleincome countries (LMICs). ${ }^{[13]}$ Deaths of women who have CS may be 
unrelated to the procedure (e.g. due to pre-eclampsia), but for many the CS may be contributory (e.g. due to a bleeding or anaesthetic complication at CS). Increasing CS rates in LMICs need to be accompanied by measures to ensure that the operations are done safely. Complications of CS include bleeding, anaesthetic adverse events, sepsis, visceral injury and thromboembolism. In many LMICs there are serious skills shortages in surgery and anaesthesia, especially in rural hospitals that are far from urban centres and have limited back-up to manage complications.

\section{CS rates in SA}

The provincial public sector CS rates for 2006 and 2015, and the private sector CS rates for 2015, are summarised in Table 1.

The public sector CS rates in Table 1 are based on data from the 2015/16 District Health Barometer. ${ }^{[14]}$ Public sector CS rates increased from $15.1 \%$ in 2006 to $24.1 \%$ in 2015 . The largest increases were in North West, Eastern Cape and Gauteng. There were marked differences in the CS rates between provinces (reflecting inequitable access), with the lowest rates in the predominantly rural provinces. More recent data from 2017 indicate that the CS rate had increased further to $27.4 \%$ overall. ${ }^{[15]}$ Of note, CS is not done on maternal request in the public sector.

The private sector CS rates are based on data used for a recent study that analysed 6542 births in 2015 among members of 10 medical schemes. ${ }^{[4]}$ The overall CS rate for this group was $73.2 \%$ in 2015. This is one of the highest rates in the world, and almost three times higher than that reported for the SA public sector. This trend was evident across all provinces, with the largest private-public differences in North West, Northern Cape and Free State. The high CS rate reported by the study is in line with findings of previous studies on the SA private sector. Naidoo and Moodley ${ }^{[16]}$ reported a CS rate of $65 \%$ in 2009 based on an audit of private practice. A chapter on maternal deaths in the private sector in the 2011 - 2013 Saving Mothers report gave a CS rate of $67 \%$ for the private sector. ${ }^{[17]}$ A press article reported a CS rate of $74 \%$ for members of Discovery Health, the largest medical scheme in SA. ${ }^{[18]}$ In its 2017/18 annual report $^{[19]}$ the Council for Medical Schemes reported CS rates of 60 $70 \%$ for the private sector over the period 2007 - 2017, and in its $2018 / 19$ annual report, ${ }^{[20]}$ the CS rate is reported to have increased to $>75 \%$ in 2018 .

While there is no available information on the safety of CS in the private sector, the issues related to safety of CS in the SA public sector are well documented. In line with patterns seen in other countries, the CFR for CS in SA is three times higher than for vaginal delivery. ${ }^{[21]}$ The by-province CFRs for CS overall and for CS associated with bleeding as reported by the Saving Mothers Report for $2017^{[15]}$ are summarised in Table 2.

The CS-related CFR varies across provinces, ranging from a high of 235.5 per 100000 CSs for the Free State to a low of 87.5 for the Western Cape. Death from bleeding associated with CS has been noted as a major issue in several African countries by the African Surgical Outcomes Study ${ }^{[22]}$ and by the WHO global meta-analysis of LMICs. ${ }^{[13]}$ SA appears to have a similar issue, with $19.1 \%$ of the CS-related CFR associated with bleeding. The variations between provinces in CS-related CFR and the proportion of the fatalities associated with bleeding point to differences between provinces in the safety of CS procedures. One of the key factors identified as contributing to the variation in safety of CS between provinces is the lack of appropriately skilled staff. ${ }^{[15]}$

\section{CS rate drivers and challenges for the proposed NHI}

The evidence on public sector CS rates and safety and underlying provincial inequities highlights urgent issues in the public sector, notably: (i) the importance of more equitable access to safe CS across the country; and (ii) the need to limit further increases in the CS rate, which is thought to be at a ceiling above which no further benefits would be achieved. There is also an imperative to improve safety of CS in the public sector. Doing this requires improving the skills of doctors performing surgery and anaesthesia for CS in all facilities and ensuring an appropriate enabling environment in terms of equipment, infrastructure and supplies to manage complications.

Table 2. CFR for CS by province in SA, 2017

\begin{tabular}{|c|c|c|c|}
\hline \multirow[b]{2}{*}{ Province } & \multicolumn{2}{|c|}{ CFR/100 000 CSs } & \multirow[b]{2}{*}{$\begin{array}{l}\% \text { of CS with } \\
\text { bleeding }(\mathrm{B} / \mathrm{A})\end{array}$} \\
\hline & All CS (A) & $\begin{array}{l}\text { CS with } \\
\text { bleeding (B) }\end{array}$ & \\
\hline North West & 128.1 & 45.2 & 35.3 \\
\hline Limpopo & 208.3 & 69.4 & 33.3 \\
\hline Mpumalanga & 190.6 & 41.7 & 21.9 \\
\hline Northern Cape & 111.8 & 22.4 & 20.0 \\
\hline Free State & 235.5 & 45.6 & 19.4 \\
\hline Eastern Cape & 144.5 & 24.1 & 16.7 \\
\hline Gauteng & 127.3 & 19.1 & 15.0 \\
\hline KwaZulu-Natal & 141.7 & 17.9 & 12.7 \\
\hline Western Cape & 87.5 & 10.5 & 12.0 \\
\hline SA & 145.7 & 27.8 & 19.1 \\
\hline
\end{tabular}

Table 1. CS rates (\%) in the SA public and private sectors

\begin{tabular}{|c|c|c|c|c|c|}
\hline \multirow[b]{2}{*}{ Province } & \multicolumn{2}{|c|}{ Public sector } & \multirow{2}{*}{$\begin{array}{l}\text { Private sector, } \\
2015\end{array}$} & \multirow{2}{*}{$\begin{array}{l}\text { Public sector movement, } \\
2015 \text { v. } 2006\end{array}$} & \multirow{2}{*}{$\begin{array}{l}\text { Private v. public } \\
\text { difference, } 2015\end{array}$} \\
\hline & 2006 & 2015 & & & \\
\hline North West & 12.6 & 27.6 & 86.5 & 15.0 & 59.0 \\
\hline Northern Cape & 11.0 & 16.3 & 74.7 & 5.3 & 58.4 \\
\hline Free State & 11.6 & 16.0 & 72.9 & 4.4 & 56.9 \\
\hline Limpopo & 15.1 & 22.3 & 73.4 & 7.2 & 51.1 \\
\hline Gauteng & 13.7 & 25.6 & 75.0 & 11.9 & 49.5 \\
\hline Mpumalanga & 13.1 & 19.3 & 68.2 & 6.2 & 48.8 \\
\hline KwaZulu-Natal & 21.1 & 28.8 & 76.8 & 7.6 & 48.0 \\
\hline Eastern Cape & 9.5 & 22.7 & 66.1 & 13.2 & 43.4 \\
\hline Western Cape & 19.9 & 28.1 & 68.2 & 8.2 & 40.1 \\
\hline SA & 15.1 & 24.1 & 73.6 & 9.0 & 49.5 \\
\hline
\end{tabular}


Table 3. Drivers, challenges and required action in preparing for NHI

\begin{tabular}{|c|c|c|c|}
\hline Area & $\begin{array}{l}\text { Potential drivers for } \\
\text { difference between public } \\
\text { and private sector CS rates }\end{array}$ & Comment & Challenges and required action \\
\hline \multirow[t]{2}{*}{$\begin{array}{l}\text { Women and } \\
\text { community factors }\end{array}$} & $\begin{array}{l}\text { Need: greater need for CS } \\
\text { among women using the } \\
\text { private sector due to: } \\
\text { - demographic differences } \\
\text { - higher prevalence of } \\
\text { medical conditions for } \\
\text { which CS would be } \\
\text { indicated }\end{array}$ & $\begin{array}{l}\text { Unlikely: in fact, women accessing } \\
\text { public sector services are likely to have } \\
\text { a higher prevalence of conditions for } \\
\text { which CS may be indicated to prevent } \\
\text { morbidity, such as HIV, hypertension } \\
\text { and diabetes }{ }^{[2,24]}\end{array}$ & $\begin{array}{l}\text { Research to assess and confirm the } \\
\text { underlying need for CS based on } \\
\text { demographic and health status of women }\end{array}$ \\
\hline & $\begin{array}{l}\text { Demand: greater demand for } \\
\text { CS among women belonging } \\
\text { to medical schemes }\end{array}$ & $\begin{array}{l}\text { Plausible: women in medical schemes } \\
\text { are likely to be of higher SES, }{ }^{[25]} \text { and } \\
\text { women of higher SES are more likely to } \\
\text { demand } C S^{[7]}\end{array}$ & $\begin{array}{l}\text { Research to assess the factors driving } \\
\text { demand for CS among women } \\
\text { Design and implementation of } \\
\text { information campaigns to educate women } \\
\text { on the risks and medical issues related to } \\
\text { CS and the available choices }\end{array}$ \\
\hline \multirow[t]{3}{*}{$\begin{array}{l}\text { Health professional } \\
\text { factors }\end{array}$} & $\begin{array}{l}\text { Training of private sector } \\
\text { providers different from } \\
\text { public sector providers }\end{array}$ & $\begin{array}{l}\text { Unlikely: most public and private sector } \\
\text { providers undergo the same training. } \\
\text { However, the low assisted delivery rate } \\
\text { in the private sector may reflect a lack of } \\
\text { maintaining skills }{ }^{[4]}\end{array}$ & $\begin{array}{l}\text { - Review training programmes } \\
\text { - Continuing skills training in private as } \\
\text { well as public sector } \\
\text { - Individual accreditation of competence }\end{array}$ \\
\hline & $\begin{array}{l}\text { Remuneration model in } \\
\text { private sector drives high CS } \\
\text { rates }\end{array}$ & $\begin{array}{l}\text { Potentially significant: current private } \\
\text { sector remuneration models do not } \\
\text { consider the time exposure for private } \\
\text { practitioners in NVDs }\end{array}$ & $\begin{array}{l}\text { - Review remuneration models (local and } \\
\text { international) } \\
\text { - Explore possibilities for implementing } \\
\text { time-based remuneration models for } \\
\text { deliveries }\end{array}$ \\
\hline & Medicolegal concerns & $\begin{array}{l}\text { This is a major driver: potential legal } \\
\text { liabilities associated with vaginal } \\
\text { deliveries are substantially higher than } \\
\text { for CS }\end{array}$ & $\begin{array}{l}\text { Review maternity-related legal and } \\
\text { insurance cover } \\
\text { - Review legislation to facilitate a more } \\
\text { efficient regulatory environment }\end{array}$ \\
\hline \multirow[t]{3}{*}{$\begin{array}{l}\text { Organisational and } \\
\text { system factors }\end{array}$} & $\begin{array}{l}\text { Practice model: individual } \\
\text { private practice model (v. } \\
\text { group/team public model) } \\
\text { drives high CS rate in the } \\
\text { private sector }\end{array}$ & $\begin{array}{l}\text { Potentially significant: CS offers } \\
\text { greater certainty to individual private } \\
\text { practitioners regarding scheduling and } \\
\text { duration of maternity events } \\
\text { Midwifery model of care with doctor/ } \\
\text { obstetrician back-up for complications is } \\
\text { associated with lower CS rates }^{\left[{ }^{2}\right]}\end{array}$ & $\begin{array}{l}\text { - Review practice models (local and } \\
\text { international) } \\
\text { - Encourage midwifery model of care with } \\
\text { obstetrician back-up } \\
\text { - Identify measures needed to ensure } \\
\text { equitable distribution of workload and } \\
\text { access to safe CS }\end{array}$ \\
\hline & Hospital pressures & $\begin{array}{l}\text { Uncertain: do private hospitals place } \\
\text { pressure on providers to carry out CS to } \\
\text { increase theatre time and length of stay? }\end{array}$ & $\begin{array}{l}\text { - Review provider-hospital contracting } \\
\text { arrangements }\end{array}$ \\
\hline & Monitoring and regulation & $\begin{array}{l}\text { Possible: use of guidelines and routine } \\
\text { monitoring of CS rates, indications and } \\
\text { outcomes are more established in the } \\
\text { public than in the private sector }{ }^{[15,17,21]}\end{array}$ & $\begin{array}{l}\text { - Regulatory changes to encourage } \\
\text { maternity group practices } \\
\text { - Accreditation and licensing of providers/ } \\
\text { facilities } \\
\text { - Establish guidelines } \\
\text { - Implement monitoring mechanism based } \\
\text { on the Robson classification } \\
\text { - Selective contracting/network providers }\end{array}$ \\
\hline
\end{tabular}

$\mathrm{NHI}=$ National Health Insurance; $\mathrm{CS}$ = caesarean section; $\mathrm{SES}=$ socioeconomic status; $\mathrm{NVD}=$ normal vaginal delivery

While the public sector CS rate of $27.4 \%$ in SA is in line with global trends, the private sector rate of $73 \%$ is one of the highest in the world, as is the high differential between public and private sector rates in SA. None of the reported studies have been able to provide specific obstetric indications for the high CS rate in the SA private sector, but it is possible that many are being done without any medical or obstetric indication, either on patient request or at provider suggestion.
The proposed NHI will contract for CS (and other) services from both public and private providers, presenting a key challenge: to develop strategies that allow the public sector to benefit from private sector skills and resources so that services for the entire population are improved. This is particularly important for remote rural and overloaded regional hospitals where there is a serious lack of skills and resources (such as theatre capacity) to meet the service demands for CS. However, any strategy attempting to harness the resources of 
the private sector to service the needs of the broader SA population would need to address (among others) the following challenges: (i) how to prevent the high CS rates in the private sector being reproduced in the public sector; (ii) how to harness primarily urbanbased private resources to address needs in remote rural regions; (iii) how to use private sector CS facilities to relieve service pressures on overloaded public sector district and regional hospitals that have long lists of women awaiting CS; and (iv) whether this use of private facilities can be organised in an equitable way.

The answers as to how these challenges are addressed are important for determining the logistics of implementation of NHI in the health workplace and at district level and may also be useful for other medical and surgical disciplines where similar patterns of over-servicing in the private sector may occur. The huge disparities between public and private sector CS rates provide an opportunity to examine the underlying health systems drivers in the utilisation patterns of the two systems and the strategies that would need to be adopted to ensure that care provided in the NHI environment is appropriate and efficient. We draw on a health systems framework proposed by Betrán et al. ${ }^{[9]}$ to assess interventions required in preparation for NHI to ensure that CSs are used appropriately and safely under NHI. Betrán et al. have argued that 'decisions to use CS are driven by the clinical or psychological needs of the mother or by the clinical needs of the baby, or by both. However, where frequency of use is greater than needed, the drivers fall into three broader, interconnected, and sometimes overlapping categories. These categories relate to childbearing women, families, communities, and the broader society; health professionals; and health-care systems, financing, and organisational design and cultures.' Using this higher, broader-level categorisation, we have summarised the possible drivers for the differences in the SA public and private CS rates, the challenges that these pose, and the interventions or actions that are required to address them in preparing for NHI (Table 3).

Using CS as a case study, this article has highlighted some of the issues that would need to be dealt with at micro and macro levels in preparing for NHI. As is evident in Table 3, the challenges posed by CS are complex and would have to be addressed through a range of interventions, including: research to identify the underlying problems and issues at a more granular level; education to better inform the public and providers; review of training programmes; monitoring and accreditation of providers; and review of regulations, pricing and remuneration models. If the vision of $\mathrm{NHI}$ is to be achieved, it is important to identify how its implementation in maternity services can promote universal access to necessary safe CS for all women in SA, while reducing the rate of unnecessary CS in the private sector. Developing and implementing these interventions will take time, and there is an urgent need to commence working on the areas highlighted for CS in this article.

\section{Declaration. None.}

Acknowledgements. The authors acknowledge the institutional support of the South African Medical Research Council (SAMRC), the University of Cape Town and NMG Consultants and Actuaries provided to the study authors.

Author contributions. Conceived and designed the study: GCS, SF. Analysed the data: GCS, SF, ED. Developed the article: GCS, SF, ED, JEC. Funding. GCS is employed on a contractual basis by the SAMRC and NMG Consultants and Actuaries. Support in the form of salaries was provided by the SAMRC to authors GCS and ED, and by the University of Cape Town to SF. None of these institutions had any additional role in the study design, data collection and analysis, decision to publish, or preparation of the manuscript.

Conflicts of interest. GCS is employed on a contractual basis by NMG Consultants and Actuaries, an independent consulting firm providing consulting and actuarial services to SA private health insurance funds. NMG did not have any role in the study design, data collection and analysis, decision to publish, or preparation of the manuscript. As such, there were no conflicts of interest in the conduct of the study.

1. National Department of Health, South Africa. National Health Insurance Bill. 2019. https://www.gov. za/sites/default/files/gcis_document/201908/national-health-insurance-bill-b-11-2019.pdf (accessed 10 February 2020).

2. Statistics South Africa. Mid-year population estimates 2019. Statistical release P0302. Pretoria: Stats 2. Statistics South Africa. Mid-year population estimates 2019. Statistical release P0302. Pretoria: Stats
SA, 2019. https://www.statssa.gov.za/publications/P0302/P03022019.pdf (accessed 10 February 2020). 3. Boerma T, Ronsmans C, Melesse DY, et al. Global epidemiology of use of and disparities in caesarean 3. Boerma T, Ronsmans C, Melesse DY, et al. Global epidemiology of use of and disparities in cae
sections. Lancet 2018;392(10155):1341-1348. https://doi.org/10.1016/S0140-6736(18)31928-7

sections. Lancet 2018;392(10155):1341-1348. https://doi.org/10.1016/S0140-6736(18)31928-7 4. Solanki G, Fawcus S, Daviaud E. A cross sectional analytic study of modes of delivery and caesarean
section rates in a private health insured South African population. PLoS ONE 2019;14(6):e0219020. https://doi.org/10.1371/journal.pone.0219020

5. Souza JP, Gulmezoglu A, Lumbiganon P, et al. Caesarean section without medical indications is associated with an increased risk of adverse short-term maternal outcomes: The 2004 - 2008 WHO Global Survey on Maternal and Perinatal Health. BMC Med 2010;8:71. https://doi.org/10.1186/17417015-8-71

6. Sandall J, Tribe RM, Avery L, et al. Short-term and long-term effects of caesarean section on the health of women and children. Lancet 2018;392(10155):1349-1357. https://doi.org/10.1016/S01406736(18)31930-5

7. Mazzoni A, Althabe F, Liu NH, et al. Women's preference for caesarean section: A systematic review and meta-analysis of observational studies. Br J Obstet Gynecol 2011;118(4):391-399. https://doi, org/10.1111/j.1471-0528.2010.02793.x

8. World Health Organization. WHO statement on caesarean section rates. April 2015. https://www.who. int/reproductivehealth/publications/maternal_perinatal_health/cs-statement/en/ (accessed 10 February 2020).

9. Betrán AP, Temmerman M, Kingdon C, Mohiddin A, Opiyo N, Torloni MR. Interventions to reduce unnecessary caesarean sections in healthy women and babies. Lancet 2018:392(10155):1358-1368. https://doi.org/10.1016/S0140-6736(18)31927-5

10. Low J. Caesarean section - past and present. J Obstet Gynaecol Can 2009;31(12):1131-1136. https:// doi.org/10.1016/S1701-2163(16)34373-0
d.

11. Molina G, Weiser TG, Lipsitz SR, et al. Relationship between cesarean delivery rate and maternal and 1. Molina G, Weiser TG, Lipsitz SR, et al. Relationship between cesarean delivery rate and maternal and
neonatal mortality. JAMA 2015;314(21):2263-2270. https://doi.org/10.1097/01.aoa.0000504695.85376.b3

neonatal mortality. JAMA 2015;314(21):2263-2270. https:// doi.org/10.1097/01.aoa.0000504695.85376.b3
12. Kallianidis AF, Schutte JM, van Roosmalen J, van den Akker T. Maternal mortality after cesarean section in the Netherlands. Eur J Obstet Gynecol Reprod Biol 2018;229:148-152. https://doi. section in the Netherlands. Eur
org/10.1016/.ejogrb.2018.08.586

org/10.1016/j.ejogrb.2018.08.586
13. Sobhy S, Arroyo-Manzano D, Murugesu N, et al. Maternal and perinatal mortality and complications Sobhy S, Arroyo-Manzano D, Murugesu N, et al. Maternal and perinatal mortality and complications
associated with caesarean section in low-income and middle-income countries: A systematic associated with caesarean section in low-income and middle-income countries: A systematic
review and meta-analysis. Lancet 2019;393(10184):1973-1982. https://doi.org/10.1016/S0140review and meta-analysis. Lancet 2019;393(10184):1973-1982. https://doi.org/10.1016/S0140-
$6736(18) 32386-9$ 6736(18)32386-9

14. Massyn N, Peer N, English R, Padarath A, Barron P, Day C, eds. District Health Barometer 2015/16. Durban: Health Systems Trust, 2016. https://www.hst.org.za/publications/Pages/District-HealthBarometer-201617.aspx (accessed 1 July 2020)

15. National Department of Health, South Africa. Saving Mothers 2017: Annual Report on Confidential Inquiries into Matenal Death in South Africa. Pretoria: NDoH, 2017. http://www.health.gov.za/index. php/shortcodes/2015-03-29-10-42-47/2015-04-30-08-18-10/2015-04-30-08-24-27/category/559saving-mothers?download $=3414: 2017$ - saving-mothers-annual-report (accessed 1 July 2020).

16. Naidoo RP, Moodley J. Rising rates of caesarean sections: An audit of caesarean sections in a specialist private practice. S Afr Fam Pract 2009;51(3):254-258. https://doi.org/10.1080/20786204.2009.108738 57 (accessed 1 July 2020)

17. National Department of Health, South Africa. Saving Mothers 2011 - 2013: Sixth Report of the Confidential Enquiries into Maternal Deaths in South Africa. Pretoria: NDoH, 2014. http://www. kznhealth.gov.za/mcwh/Maternal/Saving-Mothers-2011-2013-short-report.pdf (accessed 10 February 2020).

18. Wasserman $\mathrm{H}$. The $\mathrm{C}$-section rate among Discovery members is now up to three times higher than at American celebrity hospitals - here's why. Business Insider, 20 April 2019. https://www.businessinsider co.za/discovery-c-sections-natural-births-2019-4 (accessed 10 February 2020).

19. Council for Medical Schemes. Annual Report 2017/2018: A healthy industry for all. https://www. medicalschemes.com/files/Annual\%20Reports/CMS_AnnualReport2017-2018.pdf (accessed 10 February 2020).

20. Council for Medical Schemes. Annual Report 2018/19: Working together to eliminate fraud and waste. https://www.medicalschemes.com/files/Annual\%20Reports/CMSAR2018_19.pdf (accessed 10 February 2020)

21. National Department of Health, South Africa. Saving Mothers 2014 - 2016: Seventh Triennial Report on Confidential Enquiries into Maternal Deaths in South Africa: Short report. Pretoria: NDoH, 2018. https://www.westerncape.gov.za/assets/departments/health/saving_mothers_2014-16___short_ 2018. https://www.westerncape.go
report.pdf (accessed 2 July 2020).

22. Bishop D, Dyer RA, Maswime S, et al. Maternal and neonatal outcomes after caesarean delivery in the Bishop D, Dyer RA, Maswime S, et al. Maternal and neonatal outcomes after caesarean delivery in the
African Surgical Outcomes Study: A 7-day prospective observational cohort study. Lancet Glob Health 2019;7(4):e513-e522. https://doi.org/10.1016/S2214-109X(19)30036-1

23. Goméz-Olivé FX, Ali SA, Made F, et al. Regional and sex differences in the prevalence and awareness of hypertension: An H3Africa AWI-Gen study across 6 sites in sub-Saharan Africa. Glob Heart 2017;12(2):81-90. https://doi.org/10.1016/j.gheart.2017.01.007

24. Resarch and Monitoring Unit, Council for Medical Schemes. Prevalence of chronic diseases in the population covered by medical schemes in South Africa. March 2019. https://www.medicalschemes. com/files/Research\%20Briefs/Prevalenceofchronicdiseasesinthemedicalschemespopulation.pdf (accessed 1 July 2020)

25. Statistics South Africa. General household survey, 2017. Statistical release P138. Pretoria: Stats SA, 2017. http://www.statssa.gov.za/publications/P0318/P03182017.pdf (accessed 10 February 2020).

Accepted 30 March 2020. 